\title{
EXAMINING THE EFFECT OF USER SATISFACTION AND BUSINESS INTELLIGENCE SYSTEM USAGE ON INDIVIDUAL JOB PERFORMANCE
}

\author{
Amra Kapo* \\ Lejla Turulja** \\ Tarik Zaimovic s** $^{* *}$ \\ Senka Mehic ${ }^{* * * *}$
}

Received: 9. 11. 2020

Preliminary communication

Accepted: 17. 6. 2021

UDC 658:004.891

DOI https://doi.org/10.30924/mjcmi.26.2.3

\begin{abstract}
Business intelligence systems are in widespread use today due to the many business benefits. Users are one of the key stakeholders in the business intelligence process. For optimal system adaptation, the user should be able to interact with the application in order to improve its capacity to contribute to decision-making. For the business intelligence process itself to be effective, it is necessary to define the user needs regardless of the type of work they do. If the user is satisfied and thinks that the system improves his/her performance or the quality of decisions made, they will want to use it even more. System usage has sometimes been viewed as a direct reflection of system performance; however, this is difficult to define in organizations where system usage is mandatory. Business intelligence systems are especially mandatory to use,
\end{abstract}

Abstract

\section{INTRODUCTION}

Business intelligence encompasses a wide range of definitions that can be applied differentl to the different problems as they are used in large organizations and require greater investment than other systems. This is why it is important to investigate the nature of system usage and its impact on individual performance. This research model deals with determinants that represent dimensions of the information system's success theory. Those determinants are: user satisfaction, intention to use, system usage, and individual performance. Obtained results show that increased user satisfaction and intention to use, lead to increased system usage and that both the increase in user satisfaction and system usage lead to a rise in individual user performance.

Keywords: Business Intelligence (BI), individual performance, user satisfaction, system usage, voluntariness of use

explored, depending on the perspective. Likewise, organizations may have diffe ent perceptions of the concept of business intelligence, depending on the business

* Amra Kapo, School of Economics and Business, University of Sarajevo, Trg Oslobodjenja - Alije Izetbegović 1, 71000 Sarajevo, Bosnia and Herzegovina, E-mail: amra.kapo@efsa.unsa.ba, ORCID: https://orcid.org/ 00000001-5066-7696

** Lejla Turulja, School of Economics and Business, University of Sarajevo, Trg Oslobodjenja - Alije Izetbegović 1, 71000 Sarajevo, Bosnia and Herzegovina, E-mail: lejla.turulja@efsa.unsa.ba, ORCID: https://orcid.org/ 00000003-1493-8318

*** Tarik Zaimović, School of Economics and Business, University of Sarajevo, Trg Oslobodjenja - Alije Izetbegović 1, 71000 Sarajevo, Bosnia and Herzegovina, E-mail: tarik.zaimovic@efsa.unsa.ba,, ORCID: https://orcid.org/0000-0002-4084-0165

**** Senka Mehić, School of Economics and Business, University of Sarajevo, Trg Oslobodjenja - Alije Izetbegović 1,71000 Sarajevo, Bosnia and Herzegovina, E-mail: senkamehic94@gmail.com 


\section{Journal of Contemporary Management Issues}

environment in which it is used. Business intelligence is designed to provide decisionmakers with information with which they can act in a timely manner, in an appropriate place, and mode of action, making the best possible decisions for the business environment (Negash, 2004). Business intelligence is defined as "a voluntary process whereby a firm can scan and absorb information from a turbulent environment to detect an available opportunity while minimizing the threats associated with uncertainty" (Cheng et al., 2020). Business intelligence systems use many business processes, resources, users and continuously produce information that enables business decisions (Brichni et al., 2017).

Current trends and data overload create the need to invest in these systems; however, only the environment and sudden changes faced by organizations require that the business intelligence system adapts to these changes (Cook \& Nagy, 2014; Foshay \& Kuziemsky, 2014). Consequently, it is important that business intelligence systems are constantly measured and (evaluated) to ensure their constant evolution (Brichni et al., 2017). Business intelligence systems are informative: they are objectively not necessary for doing business, so the focus on customer satisfaction and their use of the system itself is an obvious imperative (Wieder et al., 2012). This imperative, therefore, needs to be realized to achieve the purpose of implementing the system itself, and its profitabilit .

As business intelligence becomes more and more integrated into firms around the world, there is a need to analyze and understand the factors that impact individual business performance. Research shows that among the two most important problems in business intelligence are increasing business performance and improving decision making (Molensky et al., 2010). Recent works emphasize the importance of integrating a business intelligence system with organizational knowledge, thereby improving an organization's decision-making, risk management, and intellectual capabilities (Mathrani, 2021; Yiu et al., 2020). On the other hand, Moyo and Loock (2021) analyze the role of cloud-based solutions in supporting the use of business intelligence. Another focus in the papers is to study the impact of business intelligence on organizational efficiency (Masa'Deh et al., 2021). Also, the focus of some authors was on the level of adoption and the importance of business process management (BPM) and business intelligence systems (BIS) in achieving better firm performance (Vugec et al., 2020; Vukšić et al., 2013). Measurements of the performance of business intelligence systems have at least three purposes: to prove that it was worth investing time and money in them (Sawka, 2000), to improve the management of business intelligence processes in terms of meeting customer needs, and to determine whether the business intelligence process itself is effective (Herring, 1996). Measurements of the business intelligence system are not as simple because its benefits are not immediately evident.

Many benefits of business intelligence are non-financial or intangible, such as increasing the quality and providing timely information (Hannula \& Pirttimaki, 2003; Nelke, 1998), so user perception is often used as a perspective to reflect system performance. Also, Ahmad et al. (2020) observe BI through the prism of economic, financial, and environmental sustainability. It is also important to emphasize that measurement of business intelligence is easier on the level of business processes than on the company level (Bordeleau et al., 2020). 
This paper analyzes the contribution of business intelligence through a widely accepted model of information systems performance (DeLone \& McLean, 1992) made up of user satisfaction, system use, and individual performance. The model was adapted from empirical research focused on business intelligence systems (Hou, 2012; Wieder et al., 2012). The model proposed in this research deals with several interdependent variables that make up the dimensions of the information systems' success and are related to the system users' perspective, opinions, attitudes, and experiences. These variables are: user satisfaction with the business intelligence system, use of a system that includes the level and intention of use, and individual contribution (DeLone and Mclean, 1992), which will be viewed in this study as individual user performance
(Hou, 2012). The model is designed to determine the relationship between system use and customer satisfaction and their further impact on individual performance.

\section{DEVELOPMENT OF CONCEPTUAL MODEL AND HYPOTHESES}

This paper tests a conceptual model that examines the impact of satisfaction and use of business intelligence systems on individual business performance and the effect of voluntariness on the use of business intelligence systems. The conceptual model is based on the theoretical assumption of information systems success theory. The conceptual model is graphically presented by Figure 1.

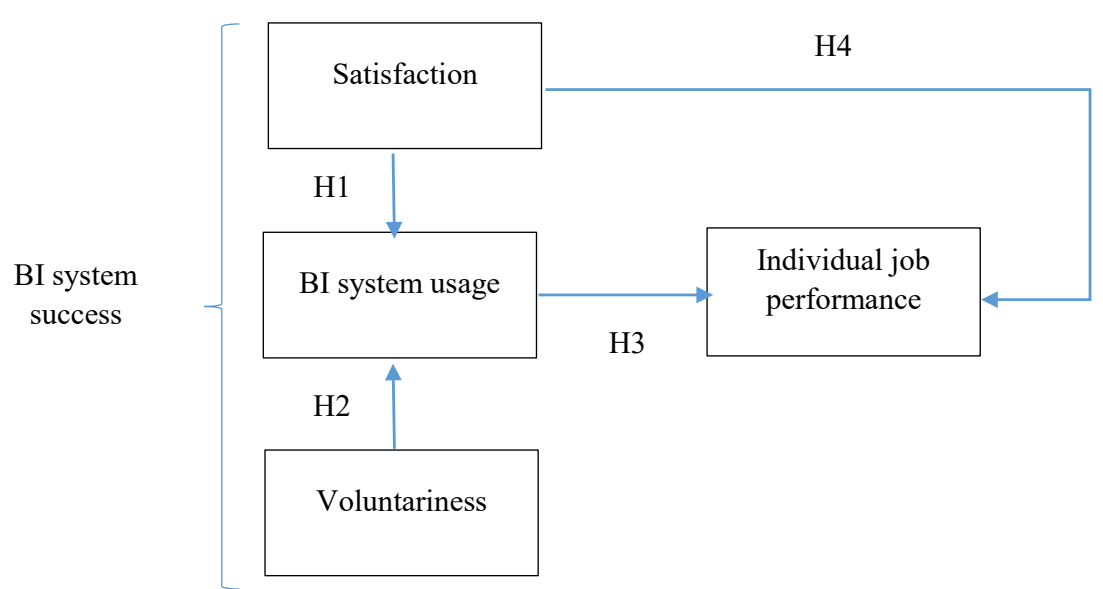

Figure 1. Conceptual model

Source: Authors.

\subsection{User satisfaction and BI system usage}

User satisfaction is defined as the degree to which users feel that the information system they use in their day-to-day business activities meets their own needs (Ives \& Olson, 1984). Satisfaction with the business intelligence system is used as a substitute indicator of the success of information systems. Also, subjective measures are used to determine satisfaction with the system as well as its performance. However, information system satisfaction is not a sufficient variable to investigate performance. 


\section{Journal of Contemporary Management Issues}

An alternative approach is defined that can more accurately show the effects of the business intelligence system: subjective measurement of the system's effectiveness. The method is based on the perceived satisfaction of the employee, decision-maker, or user, depending on the observed problem.

An additional, most commonly used measure of information system success is the use of the system. It is defined as the degree of usability by the user of the system, which is determined by modality, manner, and purpose of use (Ives and Olson, 1984). The use of the system is one of the factors that define the optimality and benefits obtained from business intelligence applications (Jooste et al., 2014). In terms of its relationship with user satisfaction researchhas found that the use of the system must precede the satisfaction with the system from the perspective of the process, but a positive experience with the system will cause increased use, which means that increased satisfaction with the system will lead to increased use (DeLone and McLean, 2003). On the other hand, the analysis of the correlation between the use of information systems and the performance of individual users has generated inconsistent results; from small to irrelevant correlation of the mentioned variables to even negative correlation. Therefore, it is necessary to examine whether it is adequate to apply the chosen model of satisfaction with the system, and if possible, connect it with the use of the system when researching the connection with individual performance (Hou, 2012).

In the past, information systems research has adopted several usage measures, including intended use, frequency of use, self-reporting (personal perception) of use and actual use (Petter et al., 2008). Usually, users who use the system often tend to underestimate or overestimate their use. Accordingly, the use not considered a strong measure, although not everyone shares this opinion. For example, Venkatesh, Thong and $\mathrm{Xu}$ (2012) found a significant connection between the intention to use and the use of the system. In general, no consensus has been found on measuring usage and whether the frequency of use is an adequate measure. One of the suggestions is to prioritize the effects rather than the frequency or length of use of the information system (Petter, DeLone and McLean, 2008).

Satisfaction was considered in this paper as an individual feeling of satisfaction, which results from comparing the observed effect to the expectations (Chiu et al., 2005). In previous research, satisfaction has very often been linked to the use of information systems (Gelderman, 1998; Pereira et al., 2015; Rouibah et al., 2009). From the stated above, we define the hypothesis

H1: Satisfaction with the business intelligence system positively influences the business intelligence (BI) system use.

Measuring IS use is a broad term that can be considered from several points of view. Urbach and Müller (2012) state that "in the case of voluntary use, the actual use of IS may be an appropriate measure of its success". The voluntariness of use in this paper is defined as "the degree to which an individual perceives that he or she has a choice to use or not use IT, is an important concept that also influences the intention to use information technology" (Kijsanayotin et al., 2009). DeLone and McLean (2003) emphasize that the intention to use has a positive effect on the actual use of the information system. However, the use of the system is a factor that is often criticized and /or neglected in research. Previous benchmark tests have used usage objectively 
by recording connection time, functionality used, or frequency of use. As argued above, the time and frequency of use do not guarantee the success of its use. Therefore, some authors resorted to subjective measures by examining the perception of the use of the system (e.g., DeLone, 1988). Petter, DeLone and McLean (2008) claim that use is a variable which is either wholly voluntary or completely mandatory. Therefore, it is important to explore both this aspect and how it affects the general use of the system. We formulated the following hypothesis:

H2: Voluntary system use has a positive influence on the business intelligence (BI) system use.

\subsection{Individual job performance}

The term individual job performance will be used to measure "the extent to which users' productivity increases" (Yim $\&$ Shin, 2014). Evaluating the success of the use of business intelligence systems is challenging, given several facts. First, there is a lack of objectively measurable variables and the heterogeneity of the systems used. Therefore, two predictors of individual performance have been discovered in the literature, namely satisfaction and use of the system, as also emphasized in previous studies by DeLone and McLean (1992), who proposed that the two are the key links with information quality and individual contribution.

The relationship between the use of information systems and the individual contribution of users is complex (Hou, 2012). Previous research has produced mixed results regarding the impact of use on individual job performance within information system research. Research by Goodhue and Thompson (1995) and Igbaria and Tan (1997) found a positive impact on individual performance, while Lucas and Spitler
(1999) study found neither a negative nor a positive impact, and Szajna and Scamell's study even found a negative effect on individual job performance.

Empirical study by Yim and Shin (2014) demonstrates the effect of information system use on individual job performance. Petter, DeLone and McLean (2008) focus on the results of several studies which have concluded that the use of the system has led to improved decision-making. Some authors have established a relationship between the duration of system use (as a measure of use) and performance (Yuthas \& Young, 1998), while others have found a positive relationship between use and task performance (Burton-Jones \& Straub, 2006) or a positive relationship between intention to use and improvement in job performance (Halawi et al., 2007). For more examples, see also Yim and Shin (2014), Livari (2005). Wu and Wang (2006).

Furthermore, it can be concluded that the extent of system usage can be a proxy of information system success and, thus, considered one of the determinants of individual business intelligence system performance. In fact, some researchers believe that information system usage directly and positively affects the perceived performance of individual users (Igbaria and Tan, 1997).

Many benefits can be derived from the use of business intelligence systems, and the most commonly cited in the literature are: efficiencye, speed and ease of access to information, IT savings, increased customer satisfaction, and improved competitiveness (Cupoli et al., 2013; Hočevar \& Jaklič, 2010). Ultimately, although the evidence on the relationship between the use of IS and individual performance is mixed, ranging from negative to moderate to positive effects, it can be assumed that information systems do not have the ability to improve 


\section{Journal of Contemporary Management Issues}

performance if end users do not use them. Goodhue and Thompson (1995) emphasize exactly this, namely that information systems must be used if improvement in individual job performance is to be achieved. Following the logic, it is expected that increased use of IS will improve individual job performance. Thus, we present the following hypothesis:

H3: The use of business intelligence (BI) systems positively influences individual job performance.

When it comes to user satisfaction with information systems, many studies have found that user satisfaction is a critical determinant of their success (DeLone \& McLean, 1992; Doll \& Torkzadeh, 1988; Igbaria \& Tan, 1997). In the post-implementation phase of the business intelligence system, customer satisfaction is one of the primary indicators and a measure of the success of the implementation itself (Sangar \& Iahad, 2013). Further, DeLone and Mclean (2003) believe that an increase in personal satisfaction with using an information system leads to an increase in the use of the system itself. Many studies attach importance to customer satisfaction as a measure of overall success in organizations (Bailey \& Pearson, 1983; Ives \& Olson, 1984). Individual user performance can indicate that an information system has provided a better understanding in the context of decision making, contributed to improved productivity, or even changed user attitudes to the importance and usefulness of the information system itself (DeLone and Mclean, 1992).

In information systems research, the positive relationship between satisfaction and individual job performance has often been studied (Petty et al., 1984; Sharabati, 2015; Tam \& Oliveira, 2016). Precisely such a link between customer satisfaction and individual performance, advertised by precise work performance, feedback, skills required to achieve efficiency and feedback, has been demonstrated by Guimaraes and Igbaria (1997). In their research, Petter, DeLone and McLean (2008) sum-marized the strong association of user sat-isfaction with the benefits of the system (Iivari, 2005). Information systems man-agement researchers have been engaged in evaluating the performance of information systems since the 1980s (Etezadi-Amoli \& Farhoomand, 1996; Schewe, 1976). However, the lack of objective measures has resulted in a measure of system quality, information quality and use, personal and organizational contribution, using user perspective and performance (DeLone and Mclean, 1992; Etezadi-Amoli and Farhoomand, 1996). In conclusion, with all stated above, we formulated hypothesis as follows:c

H4: Satisfaction with the business intelligence (BI) system positively influences individual job performance.

\section{METHODS}

A quantitative research design was used to test the conceptual model. The respondents who participated in the research were employees, with access to business intelligence systems at work.

\subsection{Research instrument}

Fourteen indicators from prior research were utilized to assess the proposed conceptual model. A complete list of measuring indicators may be found in Appendix A. The Liker scale (1 - strongly disagree; 7 - strongly agree) was used to measure the constructs in this conceptual model. 
The system usage was described by two indicators, related to satisfaction with the BI system usage. Voluntariness was described by four items. Both scales were adopted from Moore and Benbasat (1991). The operationalization of the measuring scale of end-user satisfaction with the system resulted in a first-order scale with four statements. Although there are examples of scales that consider end-user satisfaction as a multidimensional instrument (for example, Doll \& Torkzadeh (1988) measure satisfaction using five components content, accuracy, format, ease of use, and timeliness), most authors define end-user satisfaction as a one-dimensional measure (e.g., Gaardboe et al. (2017); Laumer et al. (2017); Bhattacherjee (2001)). In this regard, user satisfaction is operationalized as a one-dimensional construct in this study. Indicators are selected from Doll et al. (1994) to emphasize the content in terms of information satisfaction, and because the primary objective of business intelligence systems is to "present valuable and competitive information to business planners and decision-makers" (Khan \& Quadri, 2012). Individual job performance was measured, based on the proposed scale in the paper by Igbaria \& Tan (1997).

Table 1. List of constructs and measures

\begin{tabular}{|c|c|c|}
\hline Construct & Item & Source \\
\hline \multirow[t]{2}{*}{ SYSTEM USAGE } & $\begin{array}{l}\text { Duration of use: How much time do you spend each week } \\
\text { using BI system? }\end{array}$ & \multirow{4}{*}{$\begin{array}{l}\text { Moore and } \\
\text { Benbasat (1991) }\end{array}$} \\
\hline & $\begin{array}{l}\text { Frequency of system usage: at present, how often do you use } \\
\text { the BI system? }\end{array}$ & \\
\hline \multirow{2}{*}{ VOLUNTARINESS } & My superiors expect me to use the BI system. & \\
\hline & My use of the BI system is voluntary. & \\
\hline \multirow{4}{*}{ SATISFACTION } & The BI system provides the precise information I need. & \multirow{4}{*}{$\begin{array}{l}\text { Doll, Xia and } \\
\text { Torkzadeh (1994) }\end{array}$} \\
\hline & $\begin{array}{l}\text { The information content provided by the BI system meets my } \\
\text { needs. }\end{array}$ & \\
\hline & $\begin{array}{l}\text { The BI system provides reports that seem to be exactly what } \\
\text { I need. }\end{array}$ & \\
\hline & The BI system provides sufficient informatio & \\
\hline \multirow{4}{*}{$\begin{array}{l}\text { INDIVIDUAL JOB } \\
\text { PERFORMANCE }\end{array}$} & $\begin{array}{l}\text { Job performance: Using the BI system improves my job } \\
\text { performance. }\end{array}$ & \multirow{4}{*}{$\begin{array}{l}\text { Igbaria and Tan } \\
\text { (1997) }\end{array}$} \\
\hline & $\begin{array}{l}\text { Individual productivity: Using the BI system in my job } \\
\text { increases my productivity. }\end{array}$ & \\
\hline & $\begin{array}{l}\text { Job effectiveness: Using the BI system enhances my } \\
\text { effectiveness in my job }\end{array}$ & \\
\hline & $\begin{array}{l}\text { Decision-making quality: Using the BI system improves my } \\
\text { decision-making quality. }\end{array}$ & \\
\hline
\end{tabular}




\section{Journal of Contemporary Management Issues}

\subsection{Data collection and sample characteristics}

An electronic survey tool was used to collect the data. The research was conducted on users of business intelligence systems in several different business sectors dominated by IT, Finance, and Insurance sector.

A total of 212 respondents participated in the study. In order to maintain the validity of the participation in the research, the first question of the questionnaire was the elimination - to ensure that the research respondents are users of the business intelligence system. There was an almost equal distribution of men and women in the research $(52.4 \%$ women and $47.6 \%$ men). The level of education is distributed as follows: higher education $76 \%$, master's degree $9 \%$, secondary education $7.5 \%$, higher education $6.1 \%$, and $1.4 \%$ doctoral. Most of the respondents were aged from 25 to 34 years (56.6\% of them). Regarding employment, most respondents are operational workers $(65.1 \%) ; 6.1 \%$ of them are heads of departments, while only $1.4 \%$ belong to middle management. One-third of respondents $(27.7 \%)$ belong to the group "Other". Respondents' experience with the use of computers is as follows: $44.3 \%$ of respondents have been using computers for 6-10 years; $28.3 \%$ for $4-6$ years and $25.9 \%$ for over 10 years. Only $1.4 \%$ of respondents have been using computers for only 1-3 years. Types of the business intelligence systems used by respondents are presented by Figure 2 .

\section{BI vendors}

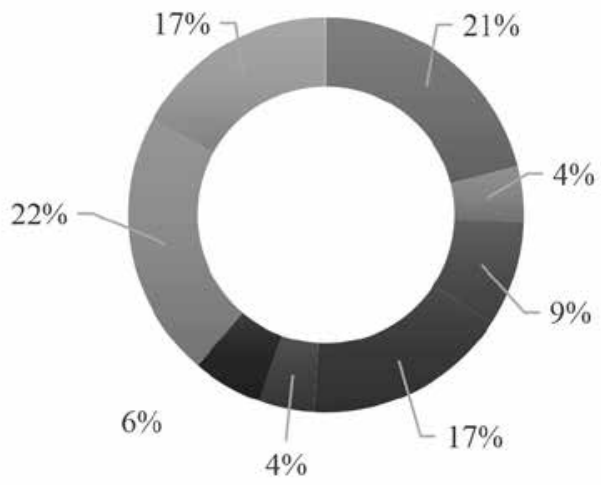

= Oracle

ISAP

- Microsoft Power BI

- IBM Cognos

- SAS

- Qlick Sense

- In house development

॥ Others

Figure 2. BI Systems used by respondents

Source: Authors.

\subsection{Statistical methods}

A number of statistical methods and techniques were used to test the conceptual model. Prior to a more detailed analysis of the collected data, we addressed the missing value analysis, outlier analysis, and assumption testing recommended by (Hair et al., 2010) for the chosen research method.

We tested the reliability of the measurement and structural model using two indicators: Cronbach Alpha coefficient and 
Composite Reliability (CR). In the next step, the convergent validity of the measurement and structural model was tested using the following three indicators: Factor loadings, average variance extracted, and $\mathrm{t}$-value. Discriminant validity is a measure that tests the diversity of constructs within a model. Fornell and Larcker (1981) emphasize that discriminant validity is tested such that the square root of the average derived variance must be greater than the correlations between constructs. In addition, various indices were used to measure the model fit. In this paper, we used goodness of fit statistics (GFI), adjusted goodness of fit statistics (AGFI), normalized goodness of fit index (NFI), non-normalized goodness of fit index (NNFI), and root mean square error (RMSEA).

\section{DATA ANALYSIS}

\subsection{Validity and reliability}

The structural equation modeling technique, used where the tested causal effect is simultaneously sought on interrelated relationships using confirmatory factor analysis, was used to test the integral influence of the constructs satisfaction, voluntariness, BI system use, and individual job performance (Hair et al. 2010). The maximum likelihood estimation (MLE) method was used to estimate the parameters in the given theoretical model. The two-step approach of Anderson and Gerbing (1988) was used. In the first step, the validity of the measurement model was evaluated, which includes the assessment of reliability and validity (convergent and discriminant). The second step aimed to test the structural model, i.e. the strength and direction of the relationships, previously assumed in the model. In other words, the overall fit of the model was evaluated

Table 2. Analysis of the reliability and convergent validity

\begin{tabular}{|c|c|c|c|c|c|c|c|c|}
\hline Construct & Item & St. loadings & t-value & CR & AVE & Mean & St. dev. & $\begin{array}{c}\text { Cronbach } \\
\text { alpha }\end{array}$ \\
\hline \multirow{4}{*}{ Satisfaction } & SAT1 & 0.851 & - & \multirow{4}{*}{0.909} & \multirow{4}{*}{0.714} & 6.15 & 0.818 & \multirow{4}{*}{0.908} \\
\hline & SAT2 & 0.878 & 16.198 & & & 6.03 & 0.859 & \\
\hline & SAT3 & 0.849 & 15.357 & & & 5.96 & 0.930 & \\
\hline & SAT4 & 0.800 & 13.995 & & & 6.10 & 0.837 & \\
\hline \multirow{2}{*}{ System usage } & US1 & 0.643 & - & \multirow{2}{*}{0.686} & \multirow{2}{*}{0.525} & 4.53 & 1.616 & \multirow{2}{*}{0.675} \\
\hline & US2 & 0.799 & 5.230 & & & 5.67 & 1.389 & \\
\hline \multirow{2}{*}{ Voluntariness } & VOL 1 & 0.697 & - & \multirow{2}{*}{0.826} & \multirow{2}{*}{0.711} & 6.78 & 0.709 & \multirow{2}{*}{0.788} \\
\hline & VOL 2 & 0.947 & 4.131 & & & 6.77 & 0.591 & \\
\hline \multirow{4}{*}{$\begin{array}{l}\text { Individual } \\
\text { performance }\end{array}$} & PER1 & 0.844 & - & \multirow{4}{*}{0.914} & \multirow{4}{*}{0.727} & 6.15 & 0.867 & \multirow{4}{*}{0.912} \\
\hline & PER2 & 0.894 & 16.720 & & & 6.09 & 0.860 & \\
\hline & PER3 & 0.885 & 16.465 & & & 6.13 & 0.861 & \\
\hline & PER4 & 0.785 & 13.589 & & & 6.12 & 0.905 & \\
\hline
\end{tabular}

Source: Authors. 


\section{Journal of Contemporary Management Issues}

Garson (2015) states that the internal consistency coefficient is a popular measure for reliability testing, which Hair et al. (2010) suggest should be no higher than $(\alpha>$ 0.5 ). As shown in Table 2, all of our coefficients in the factor loading column are higher than the recommended value and range from 0.643 to 0.947 , indicating that the criteria of reliability and internal consistency are met. Other indicators that test validity and reliability are composite reality (CR) and average variance extracted (AVE). Table 2 shows that the values are above are threshold. CR values range from 0.686 to 0.914 , while AVE has values from 0.525 to 0.727 . Moreover, t-values of more than 1.96 (for $p$ ) support validity. Thus, it was confirmed that the selected indicators significantly represent the constructs of the measurement model. Discriminant validity was tested by using Fornell \& Larcker (1981) criteria, with the results presented in Table 3 .

Table 3. Discriminant validity

\begin{tabular}{|l|c|c|c|c|}
\hline Constructs & Voluntariness & $\begin{array}{c}\text { Individual } \\
\text { performance }\end{array}$ & $\begin{array}{c}\text { System } \\
\text { usage }\end{array}$ & Satisfaction \\
\hline Voluntariness & $\mathbf{0 . 8 4 3}$ & & & \\
\hline Individual performance & 0.210 & $\mathbf{0 . 8 5 3}$ & & \\
\hline System usage & 0.318 & 0.454 & $\mathbf{0 . 7 2 5}$ & \\
\hline Satisfaction & 0.176 & 0.736 & 0.243 & $\mathbf{0 . 8 4 5}$ \\
\hline
\end{tabular}

Source: Authors.

The discriminant analysis indicates that all constructs in the measurement model differ from each other, as indicated by the fact that for each construct, the square root of the average variance extracted is greater than the correlation between constructs.

\subsection{Measurement model}

The next step in evaluating a measurement model is to analyze the fit indices (goodness of fit). The following measures were used to assess the model: $\chi^{\wedge} 2 /$ df.) $\leq 5.0$, GFI $\geq 0.90$, AGFI $\geq 0.80$, RMSEA $\geq 0.1$, NFI and NNFI $\geq 0.90$ according to (Hair et al., 2010). After testing the measurement model, we obtained the following results. The ratio of Chi-square and the number of degrees of freedom is the recommended value and is 3.801 . The root mean squared error of approximation is an acceptable value of 0.1 and indicates the adequacy of the measurement model.

Sometimes this indicator is neglected, depending on the sample size. Kenny,
Kaniskan and McCoach (2015) suggest that a small sample size and df amount can lead to a high RMSEA amount, and such results are often misleading. It is recommended not to reject the research model until other indicators are checked. Given that all other indicators are satisfactory amounts, the overall suitability of the model is acceptable. The standardized Root Mean Residual Indicator $(\mathrm{SRMR}=0.05)$ also confirms the good fit of the model. The Comparative Fit Index (CFI) has an acceptable value of 0.950 . Since all measurement model parameters are satisfactory, we can confirm that the measurement model is consistent with the collected data.

\subsection{Hypotheses testing}

Table 4 summarizes the estimated model's decomposition effects, presenting overall effects among the observed latent constructs. As noted earlier, the model in this study consists of four determinants. In the previous section, the reliability and 
validity of the measurement model were determined, so the next step is testing the integrated effec and hypotheses. Structural equation modeling was used to test the hypotheses, which enabled the analysis of several cause-and-effect relationships, and the individual parameters for each of the hypotheses were analyzed.

Table 4. Results of research hypotheses testing

\begin{tabular}{|l|l|l|l|}
\hline \multicolumn{1}{|c|}{ Research hypotheses } & \multicolumn{2}{c|}{ Standardized coefficient (t-values) } \\
\hline & Total effects & Direct effects & Indirect effects \\
\hline $\begin{array}{l}\text { H1: Satisfaction with the system } \\
\text { positively influences the BI system } \\
\text { use. }\end{array}$ & $0.283\left(2.162^{* * *}\right)$ & $0.283(2.162 * * *)$ & - \\
\hline $\begin{array}{l}\text { H2: Voluntary system use has a } \\
\text { positive influence on the BI system } \\
\text { use. }\end{array}$ & $0.629\left(3.181^{* * *}\right)$ & $0.629(3.181 * * *)$ & - \\
\hline $\begin{array}{l}\text { H3: The use of BI systems positively } \\
\text { influences individual job performance }\end{array}$ & $0.207\left(4.203^{* * *}\right)$ & $0.207(4.203 * * *)$ & - \\
\hline $\begin{array}{l}\text { H4: Satisfaction with the BI system } \\
\text { positively influences individual job } \\
\text { performance. }\end{array}$ & $0.757(10.344 * * *)$ & $0.699\left(9.822^{* * *}\right)$ & $0.059\left(2.053^{* * *}\right)$ \\
\hline $\begin{array}{l}\text { Notes: } \text { Two-tailed significance test: } \mathrm{p}<0.01=* * * \text { Fit indices for structural model: } \chi^{\wedge} 2 / \mathrm{df}=3.7, \mathrm{RMSEA}=0.1, \\
\text { SRMR = 0.05, CFI = 0.950 }\end{array}$ & & & \\
\hline
\end{tabular}

Hypothesis 1 states that satisfaction with the business intelligence system affects the system usage. Standardized evaluation parameters show that this hypothesis is statistically acceptable $(p=0.015872)$. Thus, we conclude that satisfaction with the system has a positive effect on its use.

Hypothesis 2 was also accepted ( $\mathrm{p}=$ 0.000844 ), and we can say that voluntary use positively affects business intelligence systems use. Hypothesis 3 was accepted, because the results show that it is statistically relevant $(\mathrm{p}=0.000019)$. The use of business intelligence systems has a positive effect on individual job performance. Hypothesis 4 was also accepted ( $p$ $<0.00001$ ), and it is concluded that satisfaction with the business intelligence system positively affects individual job performance. All coefficients in the structural model are statistically relevant and have the predicted direction. Detailed statistics for all variables in the structural equation modeling are presented in Figure 3. 


\section{Journal of Contemporary Management Issues}

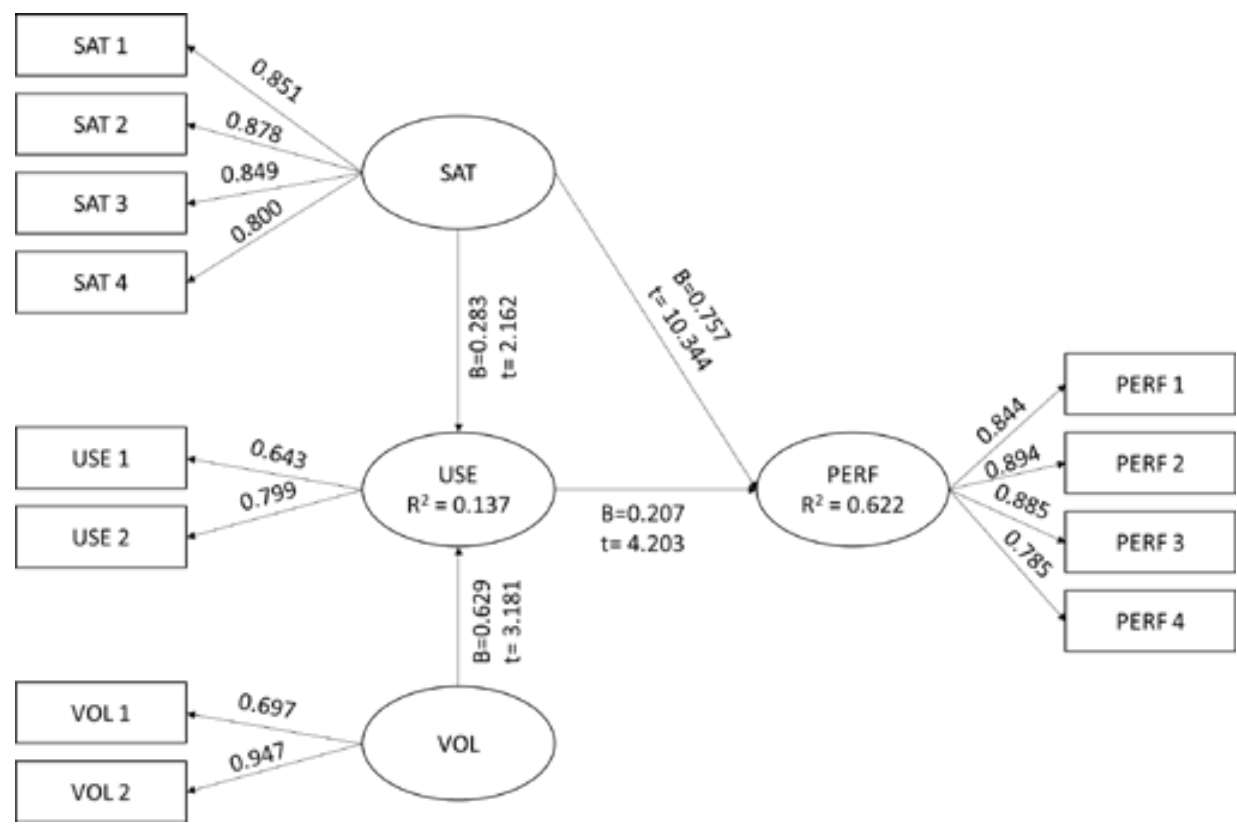

Figure 3. Structural equation model

Note: $\mathrm{SAT}=$ Satisfcation, $\mathrm{USE}=$ System usage, $\mathrm{VOL}=$ Voluntariness, $\mathrm{PERF}=$ Performance

Source: Authors.

\section{DISCUSSION AND CONCLUSION}

\subsection{Discussion}

Our research findings are in line with results of Baroudi, Olson and Ives (1986), who found that there is a significant positive relationship between system usage and customer satisfaction. More recently, Forster et al. (2020) and Salam and Farooq (2020) have reached the same conclusions. In research related to information system adoption, it is generally assumed that the greater the satisfaction, the more frequently the system is used. However, it should be emphasized that business intelligence systems require a substabtial investment, and the process of their implementation is complex. Implementing such a system has a considerable impact on a company's infrastructure which requires training and support to facilitate its usage and achieve more satisfaction among users. Hou (2014) states that the motivation to implement and use BI systems should also come from management support, with investment in training that increases the knowledge of future users and has a positive impact on building experience with systems (Hou, 2014; M Igbaria, 1993).

Similar to DeLone and Mclean (2003), the relationship between voluntariness of use and BI system use has also been demonstrated. In addition, the results show that the use of the system alone has a positive effect on individual work performance, which is consistent with many studies that have analyzed the use of the system (Goodhue and Thompson, 1995; Igbaria and Tan, 1997; Yin and Shin, 2014; Lee and 
Lee, 2012). The statistically significant impact of user satisfaction on individual performance supports Iivari (2005) and Ives and Olson, 1984) assertion that customer satisfaction can serve as a proxy for measuring individual customer performance. Measurable indicators such as financial or other data naturally provide more accurate insight into a system's performance. However, end-users are the ones who spend most time with the information system, and sometimes success is not measurable unless end-user attitudes are analyzed. The business intelligence systems themselves are primarily made for the end-users, and insight into their perspective is of great importance in a world characterised by large advances in information technology. Our results indicate that companies that use business intelligence systems could analyze the satisfaction and usage of the system to evaluate the success of the system. The results show that user satisfaction strongly influences individual performance in using the system, which is consistent with other research (Gelderman, 1998; Igbaria \& Tan, 1997; Mcgill et al., 2003). Moreover, the influence of satisfaction has a more substantial impact on individual performance than its influence on system use. We conclude that organizations can improve their employees' performance when users' satisfaction is higher, and they use the system as often as possible.

\subsection{Conclusion, limitations, and future research}

In this paper, we analyze the role of business intelligence systems in transforming business processes and resources to produce information to their customers that enable business decisions. Based on information systems success theory, the result of the analysis reveals the vital role of end-user satisfaction with BI system use as an important predictor of individual job performance. The usefulness of this system is related to the nature of an organization's business: in some companies, they are informative and are objectively not necessary for doing business, while in other companies they may be essential. The imperative for the successful implementation of a business intelligence system is the focus on customer satisfaction and their use of the system itself. The model used in the research includes customer satisfaction and the use of the system, which further affects users' performance and thus represents the success of the business intelligence system. The theoretical model was analyzed using structural equation modeling techniques, which enabled the empirical validation of the integrated model.

As already mentioned, business intelligence systems are essential in organizations that shape their daily activities and draw from the information gathered (Chen et al., 2012) To enable them to make correct business decisions of a high quality, these systems must be filled with timely, meaningful, and accurate information. The results of this research are consistent with the results of other authors. The most significant predictor of the use of business intelligence systems and predictor of individual job performance in the tested model is customer satisfaction, which has also been confirmed by previous research (Forster et al., 2020; Hou, 2012; Salam \& Farooq, 2020). Everyday use will also increase productivity and contribute to business decision-making. Given that this has a positive impact on user performance and that these users contribute to improving their organization's results, this research confirmed how important the perspective and condition of the end-user in the success of business intelligence systems. 


\section{Journal of Contemporary Management Issues}

As previously stated, the success of the business intelligence system has been insufficiently researched, so the results of this pape contribute to the field in multiple ways. Firstly, the main theoretical contribution of the paper relates to the formulation and testing of the integrated model, which outlines the determinants of the business intelligence system success. It is evident that the performance variables of IT systems have a similar relationship when we look at them through the prism of business intelligence, which is still insufficiently researched in practice. Secondly, this paper represents another successful implementation of the research model of system performance (Doll \& Torkzadeh, 1988) for business intelligence analysis from the end-user perspective. Given that research covered a diverse sample of industries, a general conclusion can be made about business intelligence systems and used in future research with a high degree of accuracy. This paper has also contributed ideas for new research on similar topics, and a comparative analysis of existing assumptions and data. Thirdly, the practical contribution lies in the fact that business intelligence systems are now examined in the developing country perspective. Managers of organizations that use these systems can gain insight into the nature of satisfaction, use, and views on the individual performance of their employees, in other words, learn about their infrastructure and user relationships with the system they use daily. The fact that they have access to such results can contribute to new activities in upgrading and advancing the system, as well as the infrastructure of the organization itself.

\subsection{Limitations and future research}

Despite the contribution, the study has some limitations that should be addressed in future research. First, the data used in this study were cross-sectional; that is, they were collected from a single sample in a single time unit. Therefore, it would be good to repeat the study to confirm the generalization of the model. Secondly, we are aware that objective measures are more desirable, so it is necessary to emphasize the additional limitation of this work, which relates to users' subjective perceptions of the use of business intelligence and its impact on employee performance. For greater applicability of the model, it is necessary to include objective measures. Finally, this research also focuses on only a few business sectors, so it may be required to collect additional profiles of the companies participating in the survey for a more indepth analysis. A significant percentage of the respondents belong to the sector that is not defined in the questionnaire, which means that a significant part of the sample that uses business intelligence systems comes from the sector(s) that is not defined. It is recommended to determine the profile of business intelligence systems users in as much detail as possible. It may not be sufficient to define their profile by the position they hold in the company. In future research, it is recommended to explore in as much detail as possible the way the system is used.

Future studies in this area should test the expanded and improved model on a larger sample to provide better ground for generalization and should supply additional information to improve the explanation power of the model. Constructs that might be of interest are organizational learning, culture, or leadership styles for individual level research. When it comes to the implementation of the business intelligence systems, Popovič et al. (2012) emphasize the importance of real user needs, such as the quality of the information provided by the system, rather than focusing on the 
technical quality (performance), which is closer to the needs of the users to make the system information more comprehensive and precise. An additional recommendation for future research is to include measurable determinants instead of subjective measures, such as comparing financial ratios after investing in business intelligence, measuring time spent on activities with and without business intelligence, etc. The fact is that this is more difficult to achieve, but for measuring the performance of a business intelligence system, the inclusion of these determinants is necessary for future research.

\section{REFERENCES}

1. Ahmad, S., Miskon, S., Alabdan, R., \& Tlili, I. (2020). Towards sustainable textile and apparel industry: Exploring the role of business intelligence systems in the era of industry 4.0. Sustainability (Switzerland), 12(7). https://doi.org/10.3390/su12072632

2. Anderson, J. C., \& Gerbing, D. W. (1988). Structural Equation Modeling in Practice: A Review and Recommended Two-Step Approach. Psychological Bulletin, 103(3), 411-423.

3. Bailey, J. E., \& Pearson, S. W. (1983). Development of a Tool for Measuring and Analyzing Computer User Satisfaction. Management Science, 29(5), 530-545. https://doi. org/10.1287/mnsc.29.5.530

4. Baroudi, J. J., Olson, M. H., \& Ives, B. (1986). An Empirical Study of the Impact of User Involvement on System Usage and Information Satisfaction. Communications of the $A C M, \quad 29(3), \quad 232-238$. https://doi. org/10.1145/5666.5669
5. Bordeleau, F. E., Mosconi, E., \& de Santa-Eulalia, L. A. (2020). Business intelligence and analytics value creation in Industry 4.0: a multiple case study in manufacturing medium enterprises. Production Planning and Control, 31(2-3), 173-185. https://doi. org/10.1080/09537287.2019.1631458

6. Brichni, M., Dupuy-Chessa, S., Gzara, L., Mandran, N., \& Jeannet, C. (2017). BI4BI: A continuous evaluation system for Business Intelligence systems. Expert Systems with Applications, 76, 97-112. https://doi.org/10.1016/j. eswa.2017.01.018

7. Burton-Jones, A., \& Straub, D. W. (2006). Reconceptualizing system usage: An approach and empirical test. Information Systems Research, 17(3), 228-246. https://doi.org/10.1287/ isre. 1060.0096

8. Chen, H., Chiang, R. H. L., \& Storey, V. C. (2012). Business Intelligence and Analytics: From Big Data to Big Impact. Management Information Systems Quarterly, 36(4), 1165-1188. https://doi. org/10.1145/2463676.2463712

9. Cheng, C., Zhong, H., \& Cao, L. (2020). Facilitating speed of internationalization: The roles of business intelligence and organizational agility. Journal of Business Research, 110 (February 2019), 95-103. https:// doi.org/10.1016/j.jbusres.2020.01.003

10. Chiu, C. M., Hsu, M. H., Sun, S Y., Lin, T. C., \& Sun, P. C. (2005). Usability, quality, value and e-learning continuance decisions. Computers and Education, 45, 399-416. https://doi. org/10.1016/j.compedu.2004.06.001

11. Cook, T. S., \& Nagy, P. (2014). Business intelligence for the radiologist: Making your data work for you. 


\section{Journal of Contemporary Management Issues}

Journal of the American College of Radiology, 11(12), 1238-1240. https:// doi.org/10.1016/j.jacr.2014.09.008

12. Cupoli, P., Co-chair, T. P. C., \& Devlin, B. (2013). ACM Tech Pack on Business Intelligence / Data Management. Acm, March, 42. techpack.acm.org/bi/

13. DeLone, W. H., \& McLean, E. R. (1992). Information systems success: The quest for the dependent variable. Information Systems Research, 3(1), 60-95. https://doi.org/10.1287/ isre.3.1.60

14. Doll, W J, \& Torkzadeh, G. (1988). The Measurement of End-User Computing Satisfaction End-User Satisfaction The Measurement of End-User Computing Satisfaction Professor of MIS and Strategic Management The University of Toledo Gholamreza Torkzadeh Assistant Professor of Information Systems. Source: MIS Quarterly, 1213512(2), 259-274. http://www.jstor.org/ stable/248851\%0Ahttp://www.jstor. org/page/info/about/policies/terms. jsp\%0Ahttp://www.jstor.org

15. Doll, William J., Xia, W., \& Torkzadeh, G. (1994). A Confirmatory Factor Analysis of the End-User Computing Satisfaction InstrumentA Confirmatory Factor Analysis of the End-User Computing Satisfaction Instrument. MIS Quarterly, 18(4), 453-461.

16. Etezadi-Amoli, J., \& Farhoomand, A. F. (1996). A structural model of end user computing satisfaction and user performance. Information and Management, 30(2), 65-73. https://doi. org/10.1016/0378-7206(95)00052-6

17. Fornell, C., \& Larcker, Da. F. (1981). Evaluating Structural Equation Models with Unobservable Variables and Measurement Error. Journal of Marketing Research, 18(1), 39-50.

18. Forster, Y., Hergeth, S., Naujoks, F., Krems, J. F., \& Keinath, A. (2020). What and how to tell beforehand: The effect of user education on understanding, interaction and satisfaction with driving automation. Transportation Research Part F: Traffic Psychology and Behaviour, 68, 316-335. https:// doi.org/10.1016/j.trf.2019.11.017

19. Foshay, N., \& Kuziemsky, C. (2014). Towards an implementation framework for business intelligence in healthcare. International Journal of Information Management, 34(1), 20-27. https://doi. org/10.1016/j.ijinfomgt.2013.09.003

20. Garson, G. D. (2015). Structural equation modeling. Statistical Publishing Associates.

21. Gelderman, M. (1998). The relation between user satisfaction, usage of information systems and performance. Information and Management, 34(1), 11-18. https://doi.org/10.1016/ S0378-7206(98)00044-5

22. Goodhue, D. L., \& Thompson, R. L. (1995). Task-Technology Fit and Individual Performance. MIS Quarterly, 19(2), 213-236.

23. Guimaraes, T., \& Igbaria, M. (1997). Client/Server System Success: Exploring the Human Side. Decision Sciences, 28(4), 851-876. https:// doi.org/10.1111/j.1540-5915.1997. tb01334.x

24. Hair, J.F., Black, W.C., Babin, B.J., Anderson, R. E. (2010). Multivariate Data Analysis (7th Edition). Prentice Hall; 7 edition.

25. Halawi, L. A., McCarthy, R. V., \& Aronson, J. E. (2007). An empirical investigation of knowledge-management systems' success. The Journal of 
Computer Information Systems, 48(2), 121-135.

26. Hannula, M., \& Pirttimaki, V. (2003). Business intelligence empirical study on the top 50 Finnish companies. Journal of American Academy of Business, Cambridge, 2(2).

27. Herring, J. (1996). Measuring the Value of Competitive Intelligence: Accessing \& Communicating CI's Value to Your Organization. SCIP Monograph Series.

28. Hočevar, B., \& Jaklič, J. (2010). Assessing benefits of business intelligence systems - A case study. Management, 15, 87-119.

29. Hou, C. K. (2012). Examining the effect of user satisfaction on system usage and individual performance with business intelligence systems: An empirical study of Taiwan's electronics industry. International Journal of Information Management, 32(6), 560-573. https://doi.org/10.1016/j. ijinfomgt.2012.03.001

30. Hou, C. K. (2014). Exploring the user acceptance of business intelligence systems in Taiwan's electronics industry: applying the UTAUT model. International Journal of Internet and Enterprise Management, 8(3), 195. https://doi.org/10.1504/ijiem.2014.059177

31. Igbaria, M. (1993). User acceptance of microcomputer technology: An empirical test. Omega, 21(1), 73-90. https://doi. org/10.1016/0305-0483(93)90040-R

32. Igbaria, Magrid, \& Tan, M. (1997). The consequences of information technology acceptance on subsequent individual performance. Information and Management, 32(3), 113-121. https://doi.org/10.1016/ S0378-7206(97)00006-2
33. Iivari, J. (2005). An Empirical Test of the DeLone-McLean Model of Information System Success. Data Base for Advances in Information Systems, 36(2), 8-27. https://doi. org/10.1145/1066149.1066152

34. Ives, B., \& Olson, M. H. (1984). User Involvement and MIS Success : A Review of Research User Involvement and MIS Success: A Review of Research. 30(5), 586-603.

35. Jooste, C., Biljon, J. Van, \& Mentz, J. (2014). Usability evaluation for Business Intelligence applications: A user support perspective. South African Computer Journal, 53, 145-153. http:// journals.co.za/content/comp/2000/26/ EJC27890

36. Kenny, D. A., Kaniskan, B., \& McCoach, D. B. (2015). The Performance of RMSEA in Models With Small Degrees of Freedom. Sociological Methods and Research, 44(3), 486-507. https://doi. org/10.1177/0049124114543236

37. Kijsanayotin, B., Pannarunothai, S., \& Speedie, S. M. (2009). Factors influencing health information technology adoption in Thailand's community health centers: Applying the UTAUT model. International Journal of Medical Informatics, 78, 404-416. https://doi.org/10.1016/j. ijmedinf.2008.12.005

38. Lucas, H. C., \& Spitler, V. K. (1999). Technology use and performance: A field study of broker workstations. Decision Sciences, 30(2), 291-311. https://doi.org/10.1111/j.1540-5915.1999. tb01611.x

39. Masa'Deh, R., Obeidat, Z., Maqableh, M., \& Shah, M. (2021). The Impact Of Business Intelligence Systems 


\section{Journal of Contemporary Management Issues}

on an Organization's Effect veness: The Role of Metadata Quality From a Developing Country'sView. International Journal of Hospitality and Tourism Administration, 22(1), 6484. https://doi.org/10.1080/15256480.2 018.1547239

40. Mathrani, S. (2021). Critical business intelligence practices to create meta-knowledge. International Journal of Business Information Systems, 36(1), 1-20. https://doi.org/10.1504/ IJBIS.2021.112413

41. Mcgill, T., Hobbs, V., \& Klobas, J. (2003). User-Developed Applications and c n Information Systems Success : A Test $\mathrm{p} u$ ro of DeLone and McLean Model. Information Resources Management Journal, 16(1), 24-45.

42. Molensky, L., Ketter, W., Collins, J., Bloemhof, J., \& Van De Koppel, H. (2010). Business intelligence gap analysis: A user, supplier and academic perspective. $A C M$ International Conference Proceeding Series, 119-128. https://doi. org/10.1145/2389376.2389393

43. Moyo, M., \& Loock, M. (2021). Conceptualising a Cloud Business Intelligence Security Evaluation Framework for Small and Medium Enterprises in Small Towns of the Limpopo Province, South Africa.

44. Negash, S. (2004). Business intelligence maturity | Business Intelligence. Communications of the Association for Information Systems, 13(January), 177-195. https://doi. org/10.17705/1CAIS.01315

45. Nelke, M. (1998). Knowledge Management in Swedish Corporations. The Value of information and Information Services.
Swedish Association for Information Specialists, Documentation.

46. Pereira, F. A. D. ., Saraiva, A., Ramos, M., Aparecida, M., \& Freitas, M. (2015). Computers in Human Behavior Satisfaction and continuous use intention of e-learning service in Brazilian public organizations. Computers in Human Behavior, 46, 139-148. https:// doi.org/10.1016/j.chb.2015.01.016

47. Petter, S., DeLone, W., \& McLean, E. (2008). Measuring information systems success: models, dimensions, measures, and interrelationships. European Journal of Information Systems, 17(3), 236-263. https://doi.org/10.1057/ ejis.2008.15

48. Petty, M. M., McGee, G. W., \& Cavender, J. W. (1984). A Meta-Analysis of the Relationships Between Individual Job Satisfaction and Individual Performance. Academy of Management Review, 9(4), 712-721. https://doi. org/10.5465/amr.1984.4277608

49. Popovič, A., Hackney, R., Coelho, P. S., \& Jaklič, J. (2012). Towards business intelligence systems success: Effects of maturity and culture on analytical decision making. Decision Support Systems, 54(1), 729-739. https://doi.org/10.1016/j.dss.2012.08.017

50. Rouibah, K., Hamdy, H. I., \& Al-Enezi, M. Z. (2009). Effect of management support, training, and user involvement on system usage and satisfaction in Kuwait. Industrial Management and Data Systems, 109(3), 338-356. https:// doi.org/10.1108/02635570910939371

51. Salam, M., \& Farooq, M. S. (2020). Does sociability quality of web-based collaborative learning information system influence students' satisfaction and system usage? International Journal of Educational Technology in 
Higher Education, 17(1). https://doi. org/10.1186/s41239-020-00189-z

52. Sangar, A. B., \& Iahad, N. B. A. (2013). Critical factors that affect the success of business intelligence systems BIS implementation in an organization. Critical Factors That Affect the Success of Business Intelligence Systems BIS Implementation in an Organization, 2(2), 176-180.

53. Sawka, K. (2000). Are we valuable? Competitive Intelligence Magazine, 3(2).

54. Schewe, C. D. (1976). The Management Information System User: An Exploratory Behavioral Analysis. Academy of Management Journal, 19(4), 577-590. https://doi.org/10.5465/255792

55. Sharabati, M. M. N. (2015). End User Satisfaction and Individual Performance Assessments in e-Procurement Systems. International Journal of Computer Theory and Engineering, 7(6), 503-509. https://doi.org/10.7763/ ijcte.2015.v7.1010

56. Suša Vugec, D., Bosilj Vukšić, V., Pejić Bach, M., Jaklič, J., \& Indihar Štemberger, M. (2020). Business intelligence and organizational performance: The role of alignment with business process management. Business Process Management Journal, 26(6), 1709-1730. https://doi. org/10.1108/BPMJ-08-2019-0342

57. Tam, C., \& Oliveira, T. (2016). Understanding the impact of $\mathrm{m}$ banking on individual performance: DeLone \& McLean and TTF perspective. Computers in Human Behavior, 61, 233-244. https://doi.org/10.1016/j. chb.2016.03.016

58. Urbach, N., \& Müller, B. (2012). The Updated DeLone and McLean Model of Information Systems Success. Informations Systems
Theory, 2, 461 . https://doi. org/10.1007/978-1-4419-6108-2

59. Venkatesh, V., Thong, J. Y. L., \& Xu, $X$. (2012). Consumer Acceptance and Use of Information Technology: Extending the Unified Theory. MIS Quarterly, 36(1), 157-178.

60. Vukšić, V. B., Bach, M. P., \& Popovič, A. (2013). Supporting performance management with business process management and business intelligence: A case analysis of integration and orchestration. International Journal of Information Management, 33(4), 613-619. https://doi. org/10.1016/j.ijinfomgt.2013.03.008

61. Wieder, B., Ossimitz, M., \& Chamoni, P. (2012). The Impact of Business Intelligence Tools on Performance: A User Satisfaction Paradox? International Journal of Economic Sciences and Applied Research, 5(3), 7-32.

62. Yim, S., \& Shin, M. (2014). Effects of System Quality and Information Quality on the Use and Job Performance of an Enterprise Mobility Solution for a Mobile Office with a Consideration of Task Mobility and Task Interdependence as Control Variables. Asia Pacific Journal of Information Systems, 24(2), 115-140. https://doi.org/10.14329/apjis.2014.24.2.115

63. Yiu, L. M. D., Yeung, A. C. L., \& Cheng, T. C. E. (2020). The impact of business intelligence systems on profitability and risks of firms. International Journal of Production Research, O(0), 1-24. https://doi.org/10.1080/0020754 3.2020 .1756506

64. Yuthas, K., \& Young, S. T. (1998) Material matters: Assessing the effectiveness of materials management IS. Information and Management, 33(3), 115-124. https://doi.org/10.1016/ S0378-7206(97)00028-1 


\title{
Journal of Contemporary Management Issues
}

\author{
ANALIZA EFEKTA ZADOVOLJSTVA KORISNIKA I \\ KORIŠTENJA SUSTAVA POSLOVNE INTELIGENCIJE \\ NA INDIVIDUALNE RADNE PERFORMANSE
}

\begin{abstract}
Sažetak
Sustavi poslovne inteligencije su u širokoj primjeni zbog brojnih poslovnih koristi. Korisnici, pak, spadaju u ključne dionike procesa poslovne inteligencije. Za optimalnu prilagodbu sustava, korisnik bi trebao biti u stanju stupiti u interakciju s aplikacijom, kako bi unaprijedio njezin kapacitet za doprinos poslovnim odlukama. Da bi sam process poslovne inteligencije bio učinkovit, potrebno je definirati poslovne potrebe, neovisne o vrsti posla, kojim se korisnik bavi. Ukoliko je korisnik zadovoljan i misli da sustav unapređuje individualne performanse ili kvalitetu donesenih odluka, željet će ga koristiti još i u većoj mjeri. Korištenje sustava se ponekad promatra kao izravna refleksija njegovih performansi; međutim, ovo je teško definirati u organizacijama, u kojima je korištenje sustava obvezno. Korištenje sustava poslovne inteligencije se zahtijeva u posebnoj mjeri, $s$ obzirom da se koriste $u$ velikim organizacijama i zahtijevaju veća ulaganja od drugih sustava. Iz tog je razloga potrebno istražiti prirodu korištenja sustava te njegovog utjecaja na individualne performanse. Ovaj istraživački model bavi se determinantama, koje predstavljaju dimenzije toerijskog uspjeha informacijskog sustava, a to su: zadovoljstvo korisnika, namjera i stvarno korištenja sustava te individualne performanse. Dobiveni rezultati pokazuju da povećano zadovoljstvo korisnika te namjera korištenja vode prema stvarno povećanom korištenju sustava, kao i da povećanje korisničkog zadovoljstva te korištenja sustava vode prema povećanju individualnih performansi korisnika.
\end{abstract}

Ključne riječi: poslovna inteligencija, individualne performanse, zadovoljstvo korisnika, korištenje sustava, dobrovoljnost korištenja 